\title{
Efeito de solventes em Staphylococcus aures isolados de mastite bacteriana bovina
}

Mariana Paganini Lourencini, Mirian Alves Goldner, Brenda Tiradentes Tavares, Matheus Castro Franco, Gabriel Ricardo de Souza Lima, Dirlei Molinari Donatele, Lenir Cardoso Porfirio, Ítalo Câmara de Almeida, Vinícius Borges Taquetti, Felipe Berbari Neto"

Centro de Ciências Agrarias e Engenharias, Universidade Federal do Espirito Santo (UFES), Vitória, ES, Brasil

*Autor correspondente

e-mail: berbarineto@hotmail.com

\section{Resumo}

O leite tem um papel fundamental na nutrição dos humanos por proporcionar fontes de proteínas e minerais. A mastite é uma enfermidade infecto-contagiosa que tem importância, principalmente, para os produtores de leite, por ser responsável por perdas na produção (diminuição de produção e qualidade do leite ou perda total da lactação), acarretando grandes prejuízos econômicos. Existem diversos patógenos transmitidos pelo leite para o homem. Dentre esses, o Staphilococcus aureus, importante por ser produtor de toxinas que provocam enterotoxemias. Hoje, o uso de antibiótico tornou-se abusivo, o que contribuiu para seleção de organismos resistentes. Assim, essas substâncias apresentam diminuição da eficácia, além do descarte de leite, pelo período de carência. 0 emprego de fitoterápicos apresenta-se como uma nova alternativa no combate à mastite; por não apresentar efeito maléfico quanto à presença de resíduos, devido a sua característica biodegradável, e pela boa atuação sobre microrganismos, tem sido uma alternativa de baixo custo e de ótimos resultados in vitro contra agentes patogênicos de várias doenças. 0 objetivo deste trabalho foi avaliar o efeito in vitro de diferentes solventes de extratos vegetais sobre isolados de mastite bovina de importância clínica em animais domésticos. A metodologia utilizada foi baseada em Silva (2003), realizandose as seguintes etapas: coleta das amostras dos animais, exame microbiológico do leite, identificação das cepas de $S$. aureus, antibiograma dos solventes. Foram realizadas três repetições para cada solvente adquirido comercialmente, de 100, 75, 50, 25, 10, 5, 3 e 1\% de concentração. São eles: Álcool Etílico, Álcool Metílico, Triton X-100, Dimetilsulfóxido e Propilenoglicol. Para controle positivo de crescimento utilizou-se solução fisiológica em frações iguais. Secreções lácteas foram coletadas de 20 vacas leiteiras. Estas amostras foram armazenadas em tubos rosqueados estéreis, identificados e enviados sob refrigeração em caixas de material isotérmico para a realização do exame microbiológico. Para a identificação da bactéria, foram 
observadas as características macromorfológicas das colônias e microscópicas à técnica do Gram, segundo Quinn et al. (1994). A concentração inibitória mínima (CIM) dos solventes sobre as linhagens bacterianas foi determinada com base no diâmetro dos halos de inibição, sendo estes superiores a $12 \mathrm{~mm}$. Os ensaios foram realizados em triplicata, acompanhados de controle positivo. A análise dos resultados do antibiograma dos solventes, após 24 horas em estufa, foi feita de acordo com Silva (2003). Classificou-se o inóculo de Staphylococcus aureus como Sensível, Sensibilidade Intermediária ou Resistente de acordo com as diferentes concentrações de solvente à qual foi submetida. De acordo com os resultados dos antibiogramas, nota-se que nenhuma concentração dos solventes Álcool Etílico, Álcool Metílico, Dimetilsulfóxido e Propilenoglicol possui ação inibitória in vitro sobre Staphylococcus aureus. Como exceção, o solvente Triton X-100 em todas as suas concentrações apresentou capacidade inibitória contra o agente bacteriano. 